\section{Australian Journal of \\ Crop Science}

AJCS 13(09):1526-1532 (2019)

doi: 10.21475/ajcs.19.13.09.p1794

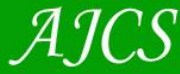

ISSN:1835-2707

\title{
Gas exchanges and growth of sesame (Sesamum indicum, L.) cultivated under saline waters and nitrogen-potassium fertilizers
}

\author{
Adaan Sudário Dias ${ }^{1}$, Geovani Soares de Lima ${ }^{2 *}$, Francisco Wesley Alves Pinheiro ${ }^{1}$, Hans Raj Gheyi ${ }^{3}$, \\ Lauriane Almeida dos Anjos Soares ${ }^{2}$, Reginaldo Gomes Nobre ${ }^{4}$, Leandro de Pádua Souza ${ }^{1}$, Saulo Soares da \\ Silva ${ }^{1}$, Sabrina Gomes de Oliveira ${ }^{2}$
}

${ }^{1}$ Federal University of Campina Grande, Academic Unit of Agricultural Engineering, Campina Grande, 58.109-970, Paraíba, Brazil

${ }^{2}$ Federal University of Campina Grande, Academic Unit of Agrarian Sciences, Pombal, 58.840-000, Paraíba, Brazil

${ }^{3}$ Federal University of Recôncavo of Bahia, Nucleus of Soil and Water Engineering, Cruz das Almas, 44.380-000, Bahia, Brazil

${ }^{4}$ Federal Rural Semiarid University, Department of Science and Technology, Caraúbas, 59.780-000, Rio Grande do Norte, Brazil

*Corresponding author: geovanisoareslima@gmail.com

Abstract

The synergistic action between $\mathrm{K}$ and $\mathrm{N}\left(\mathrm{NO}_{3}{ }^{-}\right)$favors the absorption of both ions by plants. A suitable combination of these macronutrients may be an alternative capable of alleviating the nutritional imbalance due to the excessive absorption of chloride and sodium by the plant and inhibitory competition between nitrate and potassium. In addition, it can favor the control of the turgidity of the cells, through the osmoregulation, elevate the synthesis of organic solutes, promoting the ionic homeostase, and consequently decrease the effect saline stress on the plants. In this context, this study aimed to evaluate the gas exchanges and growth of sesame cv. BRS G4 as a function of irrigation with water of increasing electrical conductivity (ECw) and fertilization with different combinations of nitrogen $(\mathrm{N})$ and potassium $(\mathrm{K})$. This experiment was conducted under greenhouse conditions. Treatments were distributed in randomized blocks and analyzed in $5 \times 4$ factorial scheme, consisting of five levels of ECw $(0.6 ; 1.2$; $1.8 ; 2.4$ and $\left.3.0 \mathrm{dS} \mathrm{m}^{-1}\right)$ and four combinations of $\mathrm{N}$ and $\mathrm{K}: \mathrm{N} / \mathrm{K}_{2} \mathrm{O}(70 / 50 ; 100 / 75 ; 130 / 100$ and 160/125\% of the recommendation

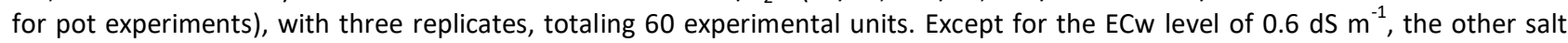
concentrations evaluated in this study compromised the gas exchanges and consequently growth of sesame cv. BRS G4, at 50 days after sowing. Fertilization with $\mathrm{N}$ and $\mathrm{K}$ in the combination of $70 / 50 \%$ of the recommendation of $\mathrm{N} / \mathrm{K}_{2} \mathrm{O}$ led to the greatest growth of sesame cv. BRS G4. The $\mathrm{N} / \mathrm{K}_{2} \mathrm{O}$ combinations of $130 / 100,160 / 125$ and $160 / 125 \%$ reduced the negative effects of saline irrigation of $1.2,1.8$ and $2.4 \mathrm{dS} \mathrm{m}^{-1}$, respectively, on the stomatal conductance of sesame plants. The combined supply of $\mathrm{N}$ and $\mathrm{K}_{2} \mathrm{O}$ in combinations of $100 / 75,130 / 100$ and $130 / 100 \%$ promoted higher $\mathrm{CO}_{2}$ assimilation rate in sesame plants using water of 1.2 and 1.8 and $2.4 \mathrm{dS} \mathrm{m}^{-1}$, respectively.

Keywords: Sesamum indicum, L., salinity, physiology, mineral fertilization.

Abbreviations: DAS_days after sowing; ECw_water electrical conductivity; PH_plant height; SD_stem diameter, NL_number of leaves LA_leaf area; $g s \_s t o m a t a l$ conductance; $A_{-}$assimilation rate, $E_{-}$transpiration; $C i$ internal $\mathrm{CO}_{2}$ concentration.

\section{Introduction}

Sesame (Sesamum indicum, L.) stands out as one of the most produced oilseed crops in the world, occupying the ninth position, whose mean production is $481.40 \mathrm{~kg} \mathrm{ha}^{-1}$. In Brazil, its mean yield is of the order of $600.0 \mathrm{~kg} \mathrm{ha}^{-1}$, being mainly used either fresh or constituting products of food and baking industry (Queiroga and Silva, 2008). According to Araújo et al. (2012), this crop has stability of production with respect to the factor water, i.e., low water requirement compared with other cultivated species. It has good adaptability to hot climate, which are important adaptive characteristics for semi-arid regions. In addition, its cultivation generates income, mainly for small producers, which makes it an excellent alternative for the socioeconomic development of this region.

However, the occurrence of high temperatures, low rainfall, irregular distribution of rains and intense evaporation, which are characteristics of the semi-arid region of Northeast Brazil, makes a successful sesame production dependent on the use of irrigation, although this crop has traits that are favorable for its planting and production in this region. It should be mentioned that the semi-arid region of Northeast Brazil faces serious problems regarding its water resources, 
because a major part of the water sources available for irrigation in this region has high concentration of dissolved salts (Souza et al., 2017).

Water with high concentrations of salts causes reduction in the soil osmotic potential, which leads to water deficit in the crops, resulting in stomatal closure, limitation on $\mathrm{CO}_{2}$ assimilation and transpiration, with consequent reduction in the photosynthetic rate (Silva et al., 2010). Besides, it causes toxicity and nutritional imbalance in plants (due to the accumulation of sodium and chloride in the tissues), culminating with the inhibition of growth and production of the crops (Pedrotti et al., 2015). Consequently, the feasibility of using these resources is associated with the development of efficient alternatives that allow these waters to be utilized (Alves et al., 2011) in the agricultural expansion of this region.

Thus, mineral fertilization, especially with nitrogen and potassium emerges as an alternative to reduce the negative effects of salinity in crops. Furthermore, $K$ is vital for photosynthesis and formation and translocation of carbohydrates (Araújo et al., 2012). It acts as an enzyme activator, improves water balance, increases water use efficiency, competes with $\mathrm{Na}^{+}$, and promotes the accumulation of $\mathrm{N}$ compounds in plants by increasing $\mathrm{N}$ use efficiency (Heidari and Jamshid, 2010). $\mathrm{N}$ is part of several organic molecules, such as amino acids, enzymes, proteins and proline, which promote the osmotic adjustment capacity of plants (Oliveira et al., 2014), mitigating the negative effects caused by salt stress on the crops.

Although the benefits of nitrogen and potassium fertilizations are recognized, little is known about their interaction as an alternative to mitigate salt stress on the sesame crop. In this context, this study aimed to evaluate the gas exchanges and growth of sesame cv. BRS G4, as a function of irrigation with water of different salinity levels and fertilization with combinations of nitrogen and potassium.

\section{Results and discussion}

Effect of saline stress and nitrogen and potassium fertilization on the gas exchange of sesame

According to the mean comparison test for stomatal conductance (Fig 1A), when sesame plants cv. BRS G4 were irrigated with highly saline water $\left(3.0 \mathrm{dS} \mathrm{m}^{-1}\right)$, no statistical differences were observed among the combinations of fertilization with $\mathrm{N} / \mathrm{K}_{2} \mathrm{O}$ at $50 \mathrm{DAS}$. In general, when sesame plants were irrigated with $1.2 \mathrm{dS} \mathrm{m}^{-1}$ saline water, the increment in $\mathrm{N} / \mathrm{K}_{2} \mathrm{O}$ ratio was increase in stomatal conductance. Plants irrigated with 2.4 and $1.8 \mathrm{dS} \mathrm{m}^{-1}$ saline water showed the highest $g s$ values $(0.143$ and $0.170 \mathrm{~mol}$ $\mathrm{H}_{2} \mathrm{O} \mathrm{m}^{-2} \mathrm{~s}^{-1}$, respectively) under fertilization with the $\mathrm{N} / \mathrm{K}_{2} \mathrm{O}$ combination of $160 / 125 \%$ (Fig 1A). Plants irrigated with 1.2 $\mathrm{dS} \mathrm{m}^{-1}$ saline water, showed the highest $g s$ values under fertilization of $130 / 100 \%$ of the $\mathrm{N}$ and $\mathrm{K}$ (of recommended dose), respectively. However, for the other $\mathrm{N} / \mathrm{K}_{2} \mathrm{O}$ combinations no significant difference was observed. In sesame plants subjected to irrigation with the lowest salinity level $\left(0.6 \mathrm{dS} \mathrm{m}^{-1}\right)$, no significant difference was found among plants which received the $\mathrm{N} / \mathrm{K}_{2} \mathrm{O}$ combinations of $70 / 50$ and $100 / 75 \%$. However, they showed higher $g s$ values compared with those under $160 / 125 \%$ of nitrogen/potassium. The highest stomatal conductance was obtained under fertilization with 70/50\% (Fig 1A).

Based on the interaction among the evaluated factors, the highest stomatal conductance was found in plants irrigated with $1.2 \mathrm{dS} \mathrm{m}^{-1}$ salinity and under $\mathrm{N} / \mathrm{K}_{2} \mathrm{O}$ combination of $130 / 100 \%$. In plants subjected to ECW of 1.8 and 2.4 and dS $\mathrm{m}^{-1}$, the best $g s$ values were observed under the combination of $160 / 100 \%$ of the recommendation for both levels of salinity (Fig 1A), indicating that increase in the combined supply of $\mathrm{N}$ and $\mathrm{K}$ positively acts by reducing the deleterious effects of irrigation water salinity on sesame $g s$. Feijão et al. (2011) explained that improvements in photosynthetic parameters are also due to the $\mathrm{N}$ status in the plant, as this nutrient is used for the synthesis of components of the photosynthetic elements. Potassium supply reduces the harmful effects of high-saline waters by acting on improvement of water balance in the plant (Gurgel et al., 2010). This favors the increase of $g s$, consequently improving gas exchanges.

For $\mathrm{CO}_{2}$ assimilation rate at 50 DAS (Fig 1B), it can be noted that plants subjected to irrigation with increased salinity levels loss $A$ and, according to the means comparison test (Fig 1B), plants irrigated with lowest salinity level $\left(0.6 \mathrm{dS} \mathrm{m}^{-1}\right)$ showed no significant difference among the different combinations of $\mathrm{N} / \mathrm{K}_{2} \mathrm{O}$. Sesame plants grown under $\mathrm{ECW}$ of $1.2 \mathrm{dS} \mathrm{m}^{-1}$ and fertilized with $100 / 75 \%$ (Fig 1B) were superior to those which received $130 / 100$ and $160 / 125 \%$ of the recommendation. Thus, it can be inferred that the response of sesame plants to the combined application of $\mathrm{N} / \mathrm{K}_{2} \mathrm{O}$ was more pronounced, when the waters of higher levels of salinity were used.

By evaluating the joint effect of water salinity and $\mathrm{N} / \mathrm{K}_{2} \mathrm{O}$ combinations, it can be noted that the increase in $\mathrm{N} / \mathrm{K}_{2} \mathrm{O}$ combinations associated with the highest salinity level (3.0

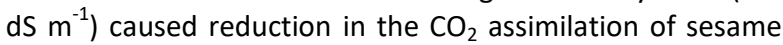
plants (Fig 1B). The sources of $\mathrm{N}$ and $\mathrm{K}_{2} \mathrm{O}$ used in the present study had salt indices of 75 and 116 , respectively (Rarder et al., 1943). The highest ECW level, associated with the highest values of the $\mathrm{N} / \mathrm{K}_{2} \mathrm{O}$ combination, intensified the effect of salt stress, due to the osmotic effect caused by the increase of salts dissolved in the irrigation water associated with the use of fertilizers (Prazeres et al., 2015).

According to the mean comparison test (Fig 1A), sesame plants subjected to irrigation using water with $\mathrm{ECW}$ of 1.2 , 1.8 and $2.4 \mathrm{dS} \mathrm{m}^{-1}$ obtained the highest $\mathrm{CO}_{2}$ assimilation rates when they were grown under combinations of $100 / 75 \%, 130 / 100 \%$ and $130 / 100 \%$ of the recommendation of $\mathrm{N} / \mathrm{K}_{2} \mathrm{O}$, respectively (Fig $1 \mathrm{~B}$ ). This indicates that the supply of these nutrients acts in combination by reducing stress caused by the $\mathrm{ECW}$, possibly due to the synergism between $\mathrm{N}$ and $\mathrm{K}$, improving the efficiency of use of these nutrients by the plant.

It is known that $\mathrm{N}$ participates in several biomolecules, such as proteins, nucleic acids, amino acids and proline (McAllister et al., 2012). Also, $\mathrm{K}$ is vital for photosynthesis, carbohydrate formation (Araújo et al., 2012) and improvement of water balance (Heidari and Jamshid, 2010), which justifies the increments in $g s$ and $A$ caused by the increase in the combined supply of $\mathrm{N}$ and $\mathrm{K}_{2} \mathrm{O}$, represented by fertilization with greater combinations of $\mathrm{N} / \mathrm{K}_{2} \mathrm{O}$. Therefore, fertilization with an adequate combination of $\mathrm{N} / \mathrm{K}_{2} \mathrm{O}$ can result in higher photosynthetic rate and greater production of photoassimilates, as well as increased 
accumulation of organic compounds, indicating that the combined supply of $\mathrm{N}$ and $\mathrm{K}$ contributes to better development of sesame under salt stress conditions.

The increase in irrigation water salinity adversely affects leaf transpiration in sesame plants cV. BRS G4. According to the regression equation (Fig $2 \mathrm{~A}$ ), the obtained data fitted best to a linear model. Transpiration decreased by $13.64 \%$ per unit increase in $\mathrm{ECW}$, which corresponded to a percentage decline of $35.65 \%$ in the $E$ of plants irrigated with of $3.0 \mathrm{dS}$ $\mathrm{m}^{-1}$ water in comparison to those subjected to ECW of $0.6 \mathrm{dS}$ $\mathrm{m}^{-1}$. This reduction in transpiration is caused by the increase in ECW due to stomatal limitation. This stands out as a defense strategy of the plant to minimize the excessive dehydration or a consequence of water imbalance in leaf epidermis (Ribeiro et al., 2009), because $E$ is closely related to stomatal opening. When stomatal conductance decreases due to the stress caused by salinity, as observed in this study (Fig 1A), there is an increase in the resistance to water diffusion from inside the leaf to the atmosphere.

The internal $\mathrm{CO}_{2}$ concentration of sesame plants $\mathrm{cV}$. BRS G4 increased linearly as the levels of irrigation water salinity increased. According to the regression equation (Fig 2B), plants irrigated with highest level of electrical conductivity $\left(3.0 \mathrm{dS} \mathrm{m}^{-1}\right.$ ) obtained $\mathrm{Ci}$ of $273.16 \mu \mathrm{mol} \mathrm{mol}{ }^{-1}$, whereas plants subjected to the lowest salinity level $\left(0.6 \mathrm{dSm}^{-1}\right)$ showed $\mathrm{Ci}$ of $197.73 \mu \mathrm{mol} \mathrm{mol}^{-1}$. In other words, there was an increment of $38.15 \%$ in the internal $\mathrm{CO}_{2}$ concentration of sesame plants irrigated with $\mathrm{ECW}$ of $3.0 \mathrm{dS} \mathrm{m}^{-1}$ compared with those subjected to $0.6 \mathrm{dS} \mathrm{m}^{-1}$. Corroborating this result, Tatagiba et al. (2014) claimed that plants subjected to salt stress exhibit reduction in stomatal conductance, leaf transpiration and photosynthesis, but the internal $\mathrm{CO}_{2}$ concentration increases. Thus, the increment in internal $\mathrm{CO}_{2}$ concentration can lead to loss of mesophyll capacity to absorb carbon, i.e., the $\mathrm{CO}_{2}$ entering the mesophyll cells is not being fixed in the carboxylation stage, possibly because of damages to their structure.

According to Freire et al. (2014), the increase of Ci within the leaves indicates that $\mathrm{CO}_{2}$ is not being used for synthesis of sugars in the photosynthetic process. This shows that some non-stomatal factor is interfering with this process, which leads to increased resistance to $\mathrm{CO}_{2}$ diffusion to the substomatal chamber.

\section{Effect of saline stress and nitrogen and potassium fertilization on sesame growth}

Based on the data presented in Fig 2, it can be observed that the increase in irrigation water salinity led to decrease in the growth of sesame cv. BRS G4 plants, reflecting the negative effects of salt stress on photosynthetic rate and increase in internal $\mathrm{CO}_{2}$ concentration in the substomatal chamber (Fig $1 \mathrm{~B}$ and $2 \mathrm{~B}$ ). According to the regression equation (Fig $2 \mathrm{C}$ ), the increase in ECW caused a $14.11 \%$ reduction in plant height per unit, corresponding to a decline of $37.01 \%$ in plants irrigated using $3.0 \mathrm{dS} \mathrm{m}^{-1}$ water, compared to those cultivated under the lowest salinity level $\left(0.6 \mathrm{dS} \mathrm{\textrm {m } ^ { - 1 }}\right)$. The reduction in SD caused by salt stress was lower than that observed for $\mathrm{PH}$, being equal to $31.91 \%$, i.e., decrease of $2.82 \mathrm{~mm}$ in the SD of sesame cv. BRS G4 plants subjected to irrigation with the highest salinity level $\left(3.0 \mathrm{dS} \mathrm{m}^{-1}\right)$, compared to the lowest ECw level (Fig 2D).
As observed for plant height and stem diameter (Fig 2C and 2D), the number of leaves of sesame cv. BRS G4 was also negatively influenced by irrigation with saline water. According to the regression equation (Fig 2E), it decreased by $9.42 \%$ per unit increase of ECW, which corresponded to a reduction of $24.01 \%$ ( 4.44 leaves) in the number of leaves of

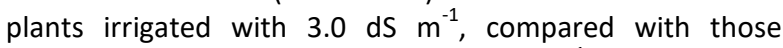
subjected to the lowest ECW level $\left(0.6 \mathrm{dS} \mathrm{m}^{-1}\right)$. For leaf area, there was greater intensity of the negative effects of water salinity. According to the regression equation (Fig 2F), the reduction in $\mathrm{LA}$ was $16.75 \%$ per unit increase in $\mathrm{ECW}$, i.e., when sesame plants were irrigated with $3.0 \mathrm{dS} \mathrm{m}^{-1}$ water. Their leaf area was on average $44.69 \mathrm{~cm}^{2}$ inferior to the value of plants subjected to $0.6 \mathrm{dS} \mathrm{\textrm {m } ^ { - 1 }}$. The deleterious effects of ECW was observed on the PH, SD, NL and LA of the sesame crop irrigated with saline water equal to or greater than $1.2 \mathrm{dS} \mathrm{m}^{-1}$, compared to plants irrigated with $0.6 \mathrm{dS} \mathrm{m}^{-1}$ (Fig 2). Therefore, it can be inferred that irrigation using

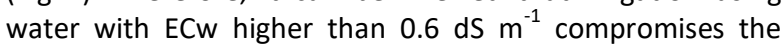
growth of sesame cv. BRS G4. Moreover, the fact that salt stress is more pronounced on sesame leaf area (Fig 2F) indicates that the stressed plants reduced not only their number of leaves but also the expansion of their leaf blade, certainly as an adaptive mechanism aiming to reduce water loss by transpiration.

The reduction in PH, SD, NL and LA of sesame cv. BRS G4 is due to the increase in the concentration of salts in the soil solution from the irrigation water, which reduces the osmotic potential of the soil, limiting water absorption by plants and consequently compromising their photosynthetic and metabolic processes (Dias et al., 2017). This causes them to reduce their energy expenditure, and as a result, there is a decrease in plant growth (Liu and Jiang, 2015). Silva et al. (2017) explained that the decline in the number of leaves and leaf area are common morphological alterations in plants under salt stress, standing out as an important adaptive mechanism of plants grown under excessively saline conditions, aiming at reduction of the transport of $\mathrm{Na}^{+}$ and $\mathrm{Cl}^{-}$in the xylem and concomitant maintenance of water in plant tissues.

Based on the mean comparison test (Fig $3 \mathrm{~A}$ ), the $\mathrm{N} / \mathrm{K}_{2} \mathrm{O}$ combination of $160: 125 \%$, which corresponded to the greater combined supply of $\mathrm{N}$ and $\mathrm{K}$, caused losses in SD, NL and LA, leading to the lowest values $(6.74 \mathrm{~mm}, 14.06$ leaves and $54.82 \mathrm{~cm}^{2}$, respectively) for these variables (Fig $3 \mathrm{~A}, 3 \mathrm{~B}$ and $3 \mathrm{C}$ ). In addition, the $\mathrm{N} / \mathrm{K}_{2} \mathrm{O}$ combinations of $70 / 50$, $100 / 75$ and $130 / 100 \%$ caused the highest values of SD, statistically differing only from the treatment with $160 / 125 \%$. Lower values of growth variables obtained from the $\mathrm{N} / \mathrm{K}_{2} \mathrm{O}$ combination of $160 / 125 \%$ are probably due to the intensification of the osmotic effect caused by the accumulation of salts in the soil, enhanced by inadequate management of fertilizers with high salt index. As already mentioned the photosynthetic rate decreased in plants irrigated with high-salinity water.

For the number of leaves (Fig 3B), sesame plants fertilized with $\mathrm{N} / \mathrm{K}_{2} \mathrm{O}$ combination of $70 / 50 \%$ differed statistically from plants subjected to the other combinations. However, when $100 / 75 \%$ is compared with $130 / 100 \%$, there was no significant difference, as observed for $130 / 100 \%$ and $160 / 125 \%$. In contrast, for leaf area (Fig 3C), plants which 
Table 1. Chemical and physical characteristics of the Eutrophic Regolithic Neosol used in the experiment*.

\begin{tabular}{|c|c|c|c|c|c|c|c|c|c|}
\hline \multicolumn{10}{|c|}{ Chemical characteristics } \\
\hline \multirow{2}{*}{$\begin{array}{l}\mathrm{pH}\left(\mathrm{H}_{2} \mathrm{O}\right) \\
(1: 2.5)\end{array}$} & \multirow{2}{*}{$\begin{array}{l}\text { OM } \\
\text { dag } \mathrm{kg}^{-1}\end{array}$} & \multirow{2}{*}{$\begin{array}{l}P \\
\left(\mathrm{mg} \mathrm{kg}^{-1}\right)\end{array}$} & $\mathrm{K}^{+}$ & $\mathrm{Na}^{+}$ & $\mathrm{Ca}^{2+}$ & $\mathrm{Mg}^{2+}$ & $\mathrm{Al}^{3+}+\mathrm{H}^{+}$ & \multirow{2}{*}{$\begin{array}{l}\text { ESP } \\
(\%)\end{array}$} & \multirow{2}{*}{ 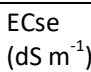 } \\
\hline & & & \multicolumn{5}{|c|}{ 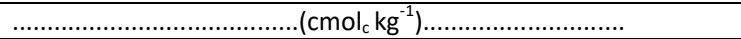 } & & \\
\hline 6.24 & 1.079 & 48.00 & 0.28 & 1.82 & 7.41 & 5.23 & 3.07 & 10.22 & 2.50 \\
\hline \multicolumn{10}{|c|}{ Physical characteristics } \\
\hline \multicolumn{3}{|c|}{ Size fraction $\left(\mathrm{g} \mathrm{kg}^{-1}\right)$} & \multirow{2}{*}{$\begin{array}{l}\text { Textural } \\
\text { class }\end{array}$} & \multicolumn{2}{|c|}{ Water content (kPa) } & \multirow[t]{2}{*}{ AW } & \multirow{2}{*}{$\begin{array}{l}\text { Total } \\
\text { porosity } \\
\mathrm{m}^{3} \mathrm{~m}^{-3}\end{array}$} & $A D$ & \multirow[t]{2}{*}{ PD } \\
\hline Sand & Silt & Clay & & $\begin{array}{l}33.42 \\
\ldots \ldots \ldots \ldots \ldots\end{array}$ & $\begin{array}{l}1519.5 \\
\text { dag } \mathrm{kg}^{-1}\end{array}$ & & & $(\mathrm{~kg} \mathrm{dm}$ & \\
\hline 656.6 & 175.0 & 168.4 & SL & 28.84 & 10.42 & 18.42 & 0.53 & 1.27 & 2.74 \\
\hline
\end{tabular}

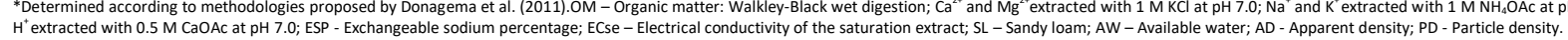
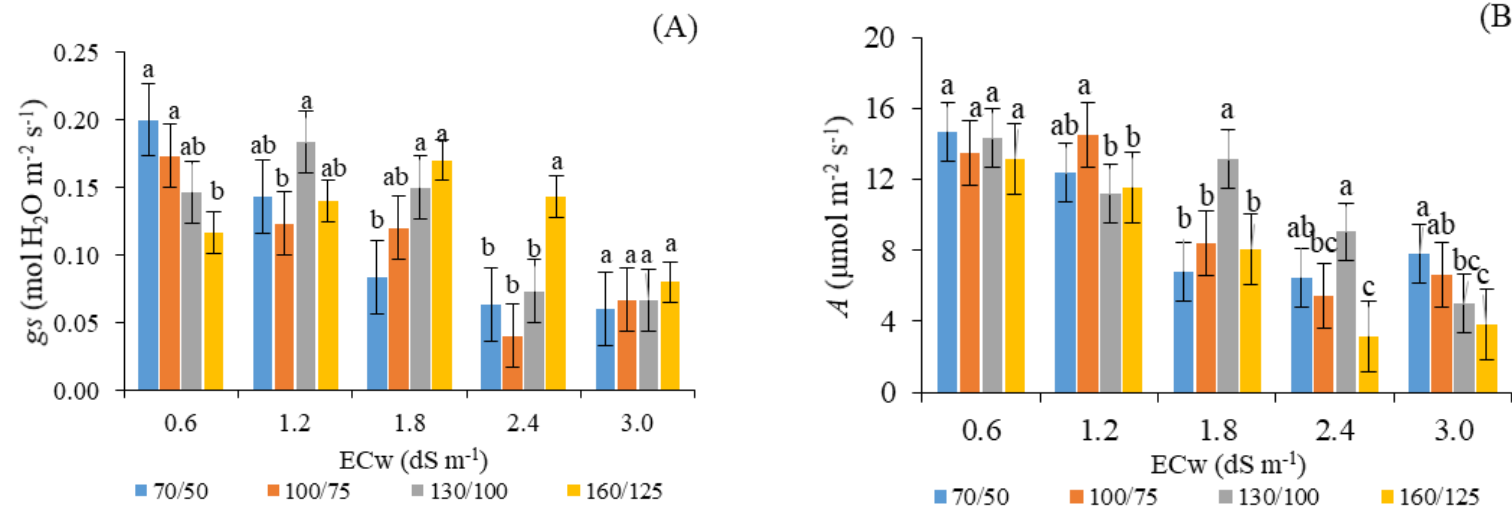

Fig 1. Stomatal conductance - gs (A) and $\mathrm{CO}_{2}$ assimilation rate $-A$ (B) of sesame cv. BRS G4, as a function of the interaction between the combination of fertilization with nitrogen and potassium $-\mathrm{N} / \mathrm{K}_{2} \mathrm{O}$ and irrigation water electrical conductivity - ECW, at 50 days after sowing. Means with different letters indicate that the treatments differ by Tukey test, $\mathrm{p}<0.05$; Bars represent mean standard error $(n=3)$.

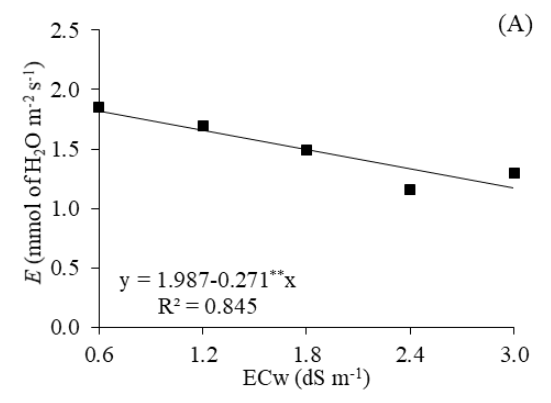

A)

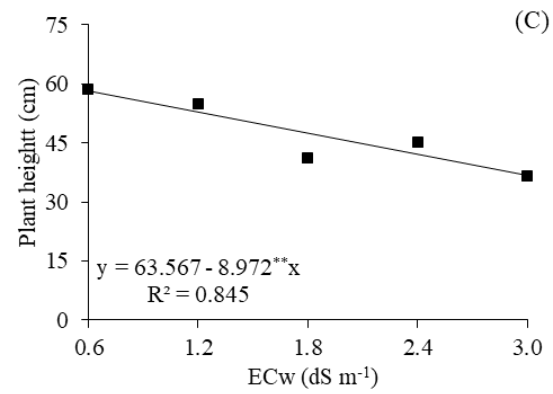

(C)
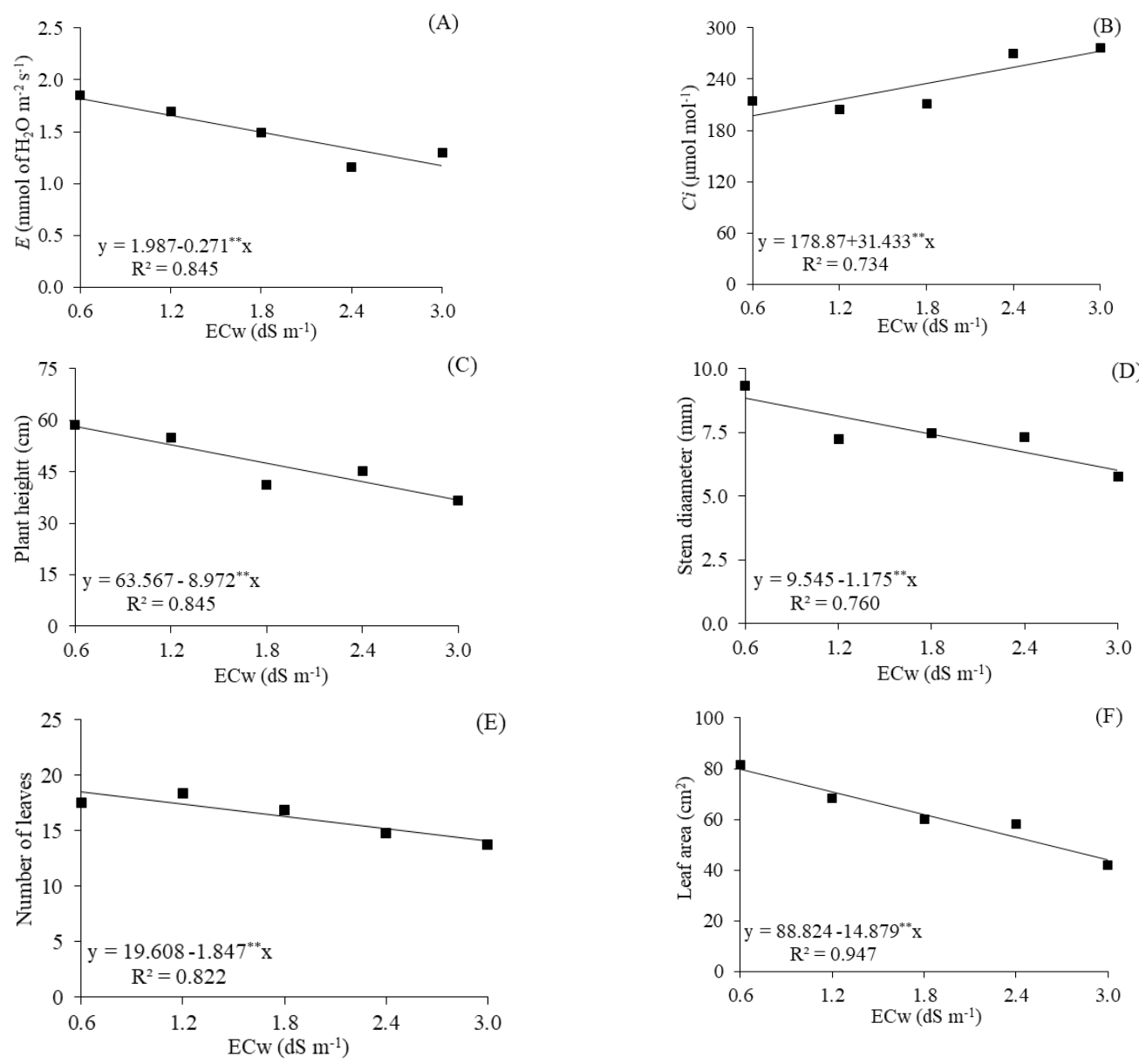

Fig 2. Transpiration $-E(A)$ and internal $\mathrm{CO}_{2}$ concentration $-\mathrm{Ci}(\mathrm{B})$, plant height $(\mathrm{C})$, stem diameter $(\mathrm{D})$, number of leaves $(\mathrm{E})$ and leaf area (F) of sesame cV. BRS G4, as a function of electrical conductivity of irrigation water - ECW, at 50 days after sowing. 

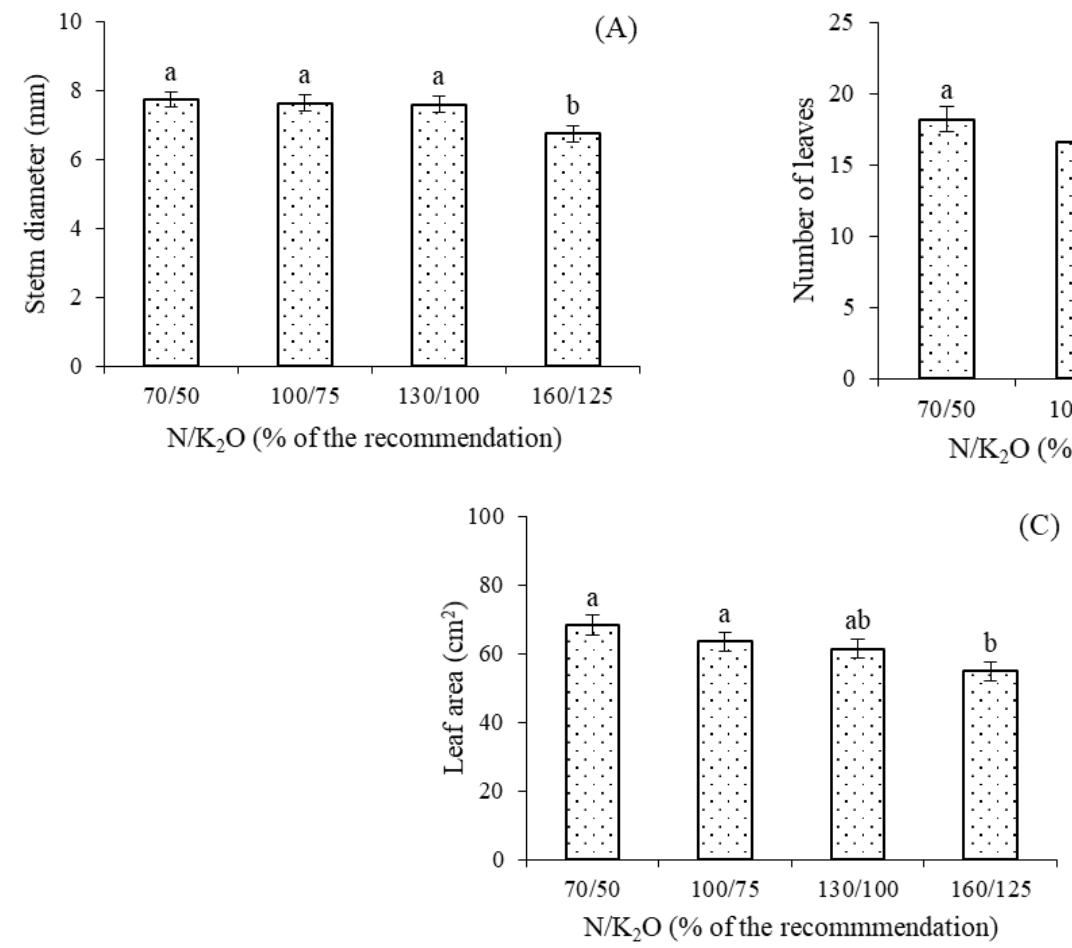

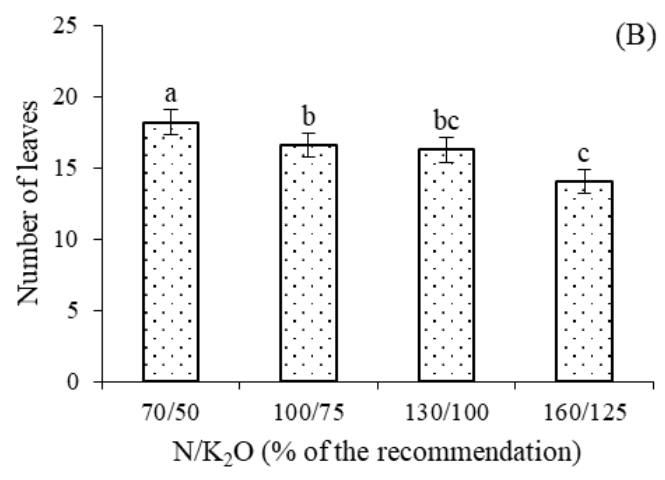

(C)

Fig 3. Stem diameter (A), number of leaves (B) and leaf area (C) of sesame cv. BRS G4, under different combination of nitrogen and potassium $-\mathrm{N} / \mathrm{K}_{2} \mathrm{O}$ fertilization and irrigated with saline waters, at 50 days after sowing; Means with different letters indicate that the treatments differ by Tukey test, $p<0.05$; Bars represent mean standard error $(n=3)$.

received the $70 / 50 \%$ combination did not differ significantly only from those fertilized with $160 / 125 \%$ of $\mathrm{N} / \mathrm{K}_{2} \mathrm{O}$. For both number of leaves and leaf area, the highest values were found using the $\mathrm{N} / \mathrm{K}_{2} \mathrm{O}$ combination of $70 / 50 \%$. Thus, it can be inferred that the combination of $70 / 50 \%$ presents itself as the best $\mathrm{N} / \mathrm{K}$ fertilization management for the crop, given the increased growth of the plants, possibly as a consequence of the better levels of stomatal conductance and $\mathrm{CO}_{2}$ assimilation rate obtained in sesame plants subjected to this combination and irrigated with $0.6 \mathrm{dS} \mathrm{m}^{-1}$ water (Fig 1). Additionally, the $\mathrm{N} / \mathrm{K}_{2} \mathrm{O}$ combination of $70 / 50 \%$ has economic importance, because it not only promotes the growth of sesame but also also represents reduction of costs related to lower requirement of inputs.

In general, plants tend to respond differently to fertilizer management, especially $\mathrm{N}$ and $\mathrm{K}$. It is known that mineral fertilizers have distinct salt indices and, in excess, can be detrimental to plant metabolism. Therefore, fertilization is of great importance in a balanced combination. Thus, the supply of $\mathrm{N}$ having urea as source contributes to the acidification of soils (Lopes, 1989) for releasing $\mathrm{H}^{+}$ions during the nitrification process, which, even at low concentration, directly affects plant growth by affecting nutrient availability. In addition, high $\mathrm{K}$ doses reduce calcium and magnesium absorption in plants due to competitive inhibition (Silva and Trevizam, 2015).

A study conducted by Lacerda et al. (2003) evaluated the growth of sorghum subjected to iso-osmotic solutions of $\mathrm{NaCl} / \mathrm{KCl}$ salts at concentrations of $0.0 / 2.0,71.5 / 0.5$, 71.0/1.0, 70.0/2.0, 68.0/4.0 and 64.0/8.0 mM applied gradually. The authors found reductions in shoot dry matter and leaf area. These authors concluded that the increase in the concentration of $\mathrm{K}^{+}$salts, particularly $\mathrm{KCl}$ can cause greater reductions in growth than $\mathrm{NaCl}$ concentrations.

\section{Materials and methods}

\section{Localization, experimental procedure, treatments}

The study was carried out under greenhouse conditions from May to July 2017, at the Center of Technology and Natural Resources of the Federal University of Campina Grande (CTRN/UFCG), located in the municipality of Campina Grande, PB, Brazil, at the geographic coordinates $7^{\circ}$ $15^{\prime} 18^{\prime \prime} \mathrm{S}, 35^{\circ} 52^{\prime} 28^{\prime \prime} \mathrm{W}$ and altitude of $550 \mathrm{~m}$. The experimental design was randomized blocks with three replicates in a $5 \times 4$ factorial scheme, and treatments consisted of five levels of irrigation water electrical conductivity - $\mathrm{ECW}\left(0.6 ; 1.2 ; 1.8 ; 2.4\right.$ and $\left.3.0 \mathrm{dS} \mathrm{m}^{-1}\right)$ and four combinations of nitrogen and potassium: $\mathrm{N} / \mathrm{K}_{2} \mathrm{O}(70 / 50$; $100 / 75 ; 130 / 100$ and $160 / 125 \%$ of the recommendation for pot experiments). The doses relative to $100 \%$ (recommended dose) corresponded to 100,300 and $150 \mathrm{mg}$ $\mathrm{kg}^{-1}$ of $\mathrm{N}, \mathrm{P}_{2} \mathrm{O}_{5}$ and $\mathrm{K}_{2} \mathrm{O}$, respectively, according to Novais et al. (1991). Nitrogen (N) and potassium (K) fertilizations were carried out at 15, 25 and 35 days after sowing (DAS), using urea as source of $\mathrm{N}$ and potassium chloride as source of $\mathrm{K}$ while $P$ was applied at sowing as super phosphate simples.

Plant material, establishment and management of the experiment

The plant material used in this study was the sesame cultivar BRS G4. Plants were grown in pots adapted as drainage lysimeters, connected at the bottom to a 4-mm-diameter 
hose to drain the leachate into a container in order to evaluate the drained water and determine water consumption by plants. The tip of the drain inside the pot was involved with a nonwoven geotextile (Bidim OP 30) to prevent clogging by soil material.

The lysimeters were filled with a $0.5-\mathrm{kg}$ layer of crushed stone (No. 0), followed by $25 \mathrm{~kg}$ of a Eutrophic Regolithic Neosol with sandy loam texture collected in the $0-20 \mathrm{~cm}$ layer, in the rural area of the municipality of Lagoa Seca, Paraíba. The soil material was properly pounded to break up clods and sieved, and its physical-hydraulic and chemical characteristics are presented in Table 1.

The irrigation waters with their respective values of electrical conductivity were prepared by dissolving the salts $\mathrm{NaCl}, \mathrm{CaCl}_{2} \cdot 2 \mathrm{H}_{2} \mathrm{O}$ and $\mathrm{MgCl}_{2} \cdot 6 \mathrm{H}_{2} \mathrm{O}$, at the equivalent proportion of 7:2:1, respectively, in water from the public supply system of Campina Grande, PB. Prior to sowing, the soil was brought to field capacity using the respective waters of each treatment. After sowing, irrigation was carried out daily by applying in each lysimeter a volume of water to maintain the soil moisture close to field capacity. The volume applied was determined based on the water requirement of the plants, estimated by water balance: volume applied minus volume drained in the previous irrigation, plus a leaching fraction of 0.10 to prevent excessive accumulation of salts in the soil.

\section{Traits measured}

The effects of the different salinity levels and combinations of $\mathrm{N}$ and $\mathrm{K}$ on the gas exchanges of sesame cv. BRS G4 were evaluated based on stomatal conductance ( $g s)$, transpiration $(E), \mathrm{CO}_{2}$ assimilation rate $(A)$ and internal $\mathrm{CO}_{2}$ concentration (Ci) using a portable Infrared Gas Analyzer (IRGA), 'LCPro +' model of ADC BioScientific Ltda. Changes caused in plant growth were also measured by collecting data of plant height $(\mathrm{PH})$, stem diameter (SD), number of leaves (NL) and leaf area (LA) at 50 DAS. PH was measured as the distance from the collar to the apical meristem and SD was measured at $2 \mathrm{~cm}$ from the collar. NL was determined by counting the leaves, and LA was determined by following the methodology described by Silva et al. (2002), through Equation 1:

$L A=0.3552 \times L^{2}$

Where; $L$ corresponds to the midrib length of the sesame leaf.

\section{Statistical analysis}

After collection, the data were subjected to analysis of variance by $F$ test and, when significant, polynomial regression analysis was carried out for the factor water salinity levels and means comparison test (Tukey test at 0.05 probability level) was applied for the combination of fertilization with $\mathrm{N}$ and $\mathrm{K}$, using the statistical software SISVAR 4.2 (Ferreira, 2011).

\section{Conclusions}

Water electrical conductivity above $0.6 \mathrm{dS} \mathrm{m}^{-1}$ compromises the gas exchanges and consequently growth of sesame cV. BRS G4, at 50 days after sowing. Fertilization with nitrogen and potassium in the combination of $70 / 50 \%$ of the recommended dose of $\mathrm{N} / \mathrm{K}_{2} \mathrm{O}$ leads to greater growth of sesame cv. BRS G4. Combinations of 130/100, 160/125 and $160 / 125 \%$ of $\mathrm{N} / \mathrm{K}_{2} \mathrm{O}$ reduce the negative effects of irrigation with water of 1.2 and 1.8 and $2.4 \mathrm{dS} \mathrm{m}^{-1}$, respectively, on the stomatal conductance of sesame plants. The combined supply of $\mathrm{N}$ and $\mathrm{K}_{2} \mathrm{O}$ in combination with 100/75, 130/100 and $130 / 100 \%$ promoted higher $\mathrm{CO}_{2}$ assimilation rate in sesame plants irrigated using water of 1.2 and 1.8 and $2.4 \mathrm{dS}$ $\mathrm{m}^{-1}$, respectively.

\section{Acknowledgements}

To the National Program of Post-Doctorate (PNPD/CAPES /UFCG), for granting the scholarship to the second author and to the National Institute of Science and Technology in Salinity - INCTSal, for funding the project.

\section{References}

Alves MS, Soares TM, Silva LT, Fernandes JP, Oliveira MLA, Paz VPS (2011) Estratégias de uso de água salobra na produção de alface em hidroponia NFT. Rev Bras Eng Agríc Ambient. 15:491-498.

Araújo HS, Quadros BR, Cardoso All, Corrêa CV (2012) Doses de potássio em cobertura na cultura da abóbora. Pesqui Agropecu Trop. 42:469-475.

Dias AS, Lima GS, Gheyi HR, Nobre RG, Santos JB (2017) Emergence, growth and production of sesame under salt stress and proportions of nitrate and ammonium. Rev Caatinga. 30:458-467.

Donagema GK, Campos DVB de, Calderano SB, Teixeira WG, Viana JHM (2011). Manual de métodos de análise de solos. 2.ed. rev. Rio de Janeiro: Embrapa Solos. 230p. (Embrapa Solos. Documentos, 132).

Feijão AR, Silva JCB, Marques EC, Prisco JT, Gomes Filho E (2011) Efeito da nutrição de nitrato na tolerância de plantas de sorgo sudão à salinidade. Rev Ciênc Agron. 42:675-683.

Ferreira DF (2011) Sisvar: A computer statistical analysis system. Ciênc Agrotec. 35:1039-1042.

Freire JLO, Dias TJ, Cavalcante LF, Fernandes PD, Lima Neto AJ (2014) Rendimento quântico e trocas gasosas em maracujazeiro amarelo sob salinidade hídrica, biofertilização e cobertura morta. Rev Ciênc Agron. 45:8291.

Gurgel MT, Gheyi HR, Oliveira FHT (2010) Acúmulo de matéria seca e nutrientes em meloeiro produzido sob estresse salino e doses de potássio. Rev Ciênc Agron. 41:18-28.

Heidari M, Jamshid P (2010) Interaction between salinity and potassium on grain yield, carbohydrate content and nutrient uptake in pearl millet. J Agric Biol Sci. 5:39-46.

Lacerda CF, Oliveira HPM, Oliveira TS, Gomes Filho E. (2003) Crescimento e acúmulo de íons em folhas de sorgo forrageiro submetido a soluções iso-osmóticas de sais $(\mathrm{NaCl}+\mathrm{KCl})$. Rev Ciênc Agron. 34:1-6. 
Liu M, Jiang Y (2015) Genotypic variation in growth and metabolic responses of perennial ryegrass exposed to short-term waterlogging and submergence stress. Plant Physiol Biochem. 95:57-64.

Lopes AS (1989) Manual de fertilidade do solo. São Paulo: ANDA/Potafós. $153 \mathrm{p}$.

McAllister CH, Beatty PH, Good AG (2012) Engineering nitrogen use efficient crop plants: The current status. Plant Biotechnol J. 10:1011-1025.

Novais RF, Neves JCL, Barros NF (1991) Ensaio em ambiente controlado. In: Oliveira AJ, Garrido WE, Araújo JD de, Lourenço $S$ (ed.) Métodos de pesquisa em fertilidade do solo. Embrapa SEA, Brasília, Brasil. p.189-253.

Oliveira FA, Medeiros JF, Alves RC, Linhares PSF, Medeiros AMA, Oliveira MKT (2014) Interação entre salinidade da água de irrigação e adubação nitrogenada na cultura da berinjela. Rev Bras Eng Agríc Ambient. 18:480-486.

Pedrotti A, Chagas RM, Ramos VC, Prata APN, Lucas AAT, Santos PB (2015) Causas e consequências dos processos de salinização dos solos. Rev Eletr Gest Educ Tecnolog Ambient. 19:1308-1324.

Prazeres SS, Lacerda CF de, Barbosa FEL, Amorim AV, Araújo ICS, Cavalcante LF (2015) Crescimento e trocas gasosas de plantas de feijão-caupi sob irrigação salina e doses de potássio. Rev Agro@mb On-line. 9:111-118.

Queiroga VP, Silva ORRF (2008) Tecnologias utilizadas no cultivo do gergelim mecanizado. Campina Grande: EMBRAPA-CNPA. 142p. (Documentos, 203).
Rader LFJR, White LM, Whittaker CW (1943) The salt index: A measure of the effect of fertilizers on the concentration of the soil solution. Soil Sci. 55:201-218.

Ribeiro RV, Machado EC, Santos MG, Oliveira RF (2009) Photosynthesis and water relations of well-watered orange plants as affected by winter and summer conditions. Photosynthetica. 47:215-222.

Silva AL, Nascimento MN, Tanan TT, Oliveira UC, Lima JC (2017) Efeito da salinidade da água de irrigação na produção de alface crespa. Encic Biosf. 14:328-337.

Silva CDS, Santos PAA, Lira JMS, Santana MC, Silva Junior CD (2010) Curso diário das trocas gasosas em plantas de feijão-caupi submetidas à deficiência hídrica. Rev Caatinga. 23:7-13.

Silva LC, Santos JW, Vieira DJ, Beltrão NEM, Alves I, Jerônimo JF (2002) Um método simples para se estimar área foliar de plantas de gergelim (Sesamum indicum L.). Rev Bras Oleag Fibrosas. 6:491-496.

Silva MLS, Trevizam, A. R. (2015) Interações iônicas e seus efeitos na nutrição das plantas. J Inform Agron. 149:10-16.

Souza, L. P, Nobre RG, Silva EM, Gheyi HR, Soares LAA (2017) Produção de porta-enxerto de goiabeira cultivado com águas de diferentes salinidades e doses de nitrogênio. Rev Ciênc Agron. 48:596-604.

Tatagiba SD, Moraes GABK, Nascimento KJT, Peloso AF (2014) Limitações fotossintéticas em folhas de plantas de tomateiro submetidas a crescente concentrações salinas. Eng Agricult. 22:138-149. 